\title{
Experimental Ehrlichia canis infection changes acute-phase proteins
}

\author{
A infecção experimental por Ehrlichia canis altera as proteínas de fase aguda \\ Thiago Demarchi Munhoz ${ }^{1}$; Joice Lara Maia Faria ${ }^{2}$; Giovanni Vargas-Hérnandez ${ }^{1}$; José Jurandir Fagliari ${ }^{1}$; \\ Áureo Evangelista Santana ${ }^{1}$; Rosangela Zacarias Machado ${ }^{3}$; Mirela Tinucci-Costa ${ }^{1 *}$ \\ ${ }^{1}$ Departamento de Clínica e Cirurgia Veterinária, Faculdade de Ciências Agrárias e Veterinárias -FCAV, \\ Universidade Estadual Paulista - UNESP, Jaboticabal, SP, Brasil \\ ${ }^{2}$ Universidade de Uberaba - UNIUBE, Uberaba, MG, Brasil \\ ${ }^{3}$ Departamento de Patologia Veterinária, Faculdade de Ciências Agrárias e Veterinárias - FCAV, \\ Universidade Estadual Paulista - UNESP, Jaboticabal, SP, Brasil
}

Received September 19, 2011

Accepted March 6, 2012

\begin{abstract}
Early diagnosis of canine ehrlichiosis favors prompt institution of treatment and improves the prognosis for the animal, since this disease causes mortality among dogs. Studies have shown that determining the concentration of acute-phase proteins (APPs) may contribute towards early detection of disease and aid in predicting the prognosis. This study aimed to evaluate the APP profile in dogs experimentally infected with Ehrlichia canis, at the start of the infection and after treatment. It also investigated whether any correlation between APP levels and the clinical and laboratory alterations over the course of the disease would be possible. The results obtained showed abnormal levels of all the APPs on the third day after infection (D3), with the highest levels being reached on D18, with the exception of ceruloplasmin and acid glycoprotein, which presented their peaks on D6 and D12 respectively. We concluded that assessment of APP levels could contribute towards establishing an early diagnosis of canine ehrlichiosis, particularly regarding acid glycoprotein and ceruloplasmin, since these proteins were detected at increased levels even before the onset of clinical and laboratory findings of the disease.
\end{abstract}

Keywords: Ehrlichia canis, experimental infection, acute-phase proteins, dogs.

\section{Resumo}

O diagnóstico precoce da erliquiose canina favorece a pronta instituição do tratamento e melhora o prognóstico do animal, pois se trata de uma doença de alta mortalidade em cáes. Estudos têm apontado que a determinaçáo da concentração de proteínas de fase aguda (PFA) pode contribuir para detecção precoce de doenças e auxiliar na predição do prognóstico. O presente estudo objetivou avaliar o perfil de proteínas de fase aguda (PFA) em cáes experimentalmente infectados com Ehrlichia canis, no início da infecção e após o tratamento. Além disso, se seria possível associá-las com as alterações clínico-laboratoriais durante o curso da doença. Os resultados obtidos evidenciaram que todas as PFA estudadas alteraram suas concentraçóes em D3 (dia 3), comparadas ao D0, atingindo concentraçóes máximas em D18, com exceção da ceruloplasmina e da glicoproteína ácida, cujos picos foram observados em D6 e D12, respectivamente. Concluímos que a avaliação das concentrações de PFA poderiam contribuir para o diagnóstico precoce da erliquiose canina, principalmente com relação à ceruloplasmina e glicoproteína ácida, pois seus aumentos foram anteriores ao aparecimento dos sinais clínicos e das alteraçôes laboratoriais da doença.

Palavras-chave: Ehrlichia canis, infecção experimental, proteínas de fase aguda, cães.

\footnotetext{
*Corresponding author: Mirela Tinucci-Costa

Departamento de Clínica e Cirurgia Veterinária, Faculdade de Ciências

Agrárias e Veterinárias - FCAV, Universidade Estadual Paulista - UNESP,

Via de Acesso Professor Paulo Donato Castelani, Km 5, Rural, CEP 14884-900,

Jaboticabal, SP, Brasil

e-mail:mirelatc@fcav.unesp.br
} 


\section{Introduction}

Canine ehrlichiosis is a disease with high incidence among domestic dogs in Brazil (DAGNONE et al., 2003; NAKAGHI et al., 2008; FARIA et al., 2010; VIEIRA et al., 2011), with extensive mortality. It is a tick-borne disease caused by Gram-negative bacteria, of the species Ehrlichia canis, mostly transmitted by Rhipicephalus sanguineus (LEWIS et al., 1977; TROY; FORRESTER, 1990). This disease has no predilection for age or sex and compromises the host's organic systems in several different ways, with varying degrees of severity (TROY; FORRESTER, 1990; CASTRO et al., 2004; NAKAGHI et al., 2008). Early diagnosis of this infection in dogs can lead to immediate treatment of the disease and, thus, may favor a better outcome.

Systemic ehrlichiosis induces an acute-phase reaction from the infected animal's immune system. This response consists of a complex reaction that triggers an increase in the levels of fibrinogen and other proteins known as acute-phase proteins (APPs), which are believed to act towards restoring homeostasis and removing the cause of the disturbance (TRAUTWEIN et al., 1994; GABAY; KUSHNER, 1999; CERÓN et al., 2005).

The acute-phase reaction is a complex defense system that anticipates the signs indicating the onset of systemic infection, which is activated in an attempt to prevent infection and contribute towards resolution of the morbid process (CRAY et al., 2009). APPs are part of the nonspecific reaction of the innate immune system, which is the organism's first line of defense at the early stages of the disease. This physiological mechanism allows time for the organism to activate other more specific lines of defense, such as cellular and humoral immune responses (CERÓN et al., 2005). Determination of APP levels could contribute towards assessing the onset of diseases and be helpful in establishing exact diagnoses (CERÓN et al., 2005).

Electrophoretic fractioning is known as one of the most trustworthy means for identifying and quantifying proteins present in body fluids and could possibly be used for assessing APPs (KANEKO et al., 1997). According to Gordon (1975), polyacrylamide gel electrophoresis containing sodium dodecyl sodium sulfate (SDS-PAGE) not only is a relatively simple and low costing technique but also would allow detection of extremely low levels of protein and identification of 20 to 30 different protein types.

The present study aimed to evaluate, using the electrophoretic fractioning assay, whether APPs (ceruloplasmin, transferrin, albumin, haptoglobin and acid glycoprotein) would become elevated during the acute phase of experimental E. canis-infections in dogs, as well as after treatment. The study also assessed correlations between these APP levels during infection development and the development and evolution of clinical signs and laboratory parameters.

\section{Materials and Methods}

The present study was approved by the Ethics Committee for Use of Animals (CEUA) of Universidade Estadual Paulista (UNESP), Jaboticabal campus (protocol no. 002460-08).
Ten dogs of mixed breed (both males and females) were used in the study. The dogs were two years old and originated from the same litter of pups bred at the experimental kennel located at the Veterinary Hospital of UNESP, in Jaboticabal. All the animals were free of ectoparasites, and had not had any prior contact with these at the time of the study. Their weights ranged from 13.3 to $19.5 \mathrm{~kg}$.

Experimental animals and time periods - Before the dogs received the inoculation, $10 \mathrm{~mL}$ of blood was taken from each animal for use in assessing the blood cells, performing nested PCR (nPCR) and investigating the presence of anti-E. canis and anti-Babesia canis serum antibodies by means of the indirect immunofluorescence test (IFAT). These tests were done to confirm that all dogs were free of infections from both of these parasites prior to inoculation. The animals were randomly allocated to two experimental groups: group A, composed of five dogs that were inoculated with $E$. canis (animals numbered A1 to A5) and group B, composed of the remaining dogs (animals numbered B1 to B5), which were kept as non-inoculated controls. The five animals in group A were inoculated using individual doses of $3 \mathrm{~mL}$ of blood infected with a sample of E. canis Jaboticabal (Gene Bank no. DQ401044), which had been previously isolated, cultured in DH82 cells and conserved in liquid nitrogen by R. Z . Machado (1993), in accordance with Buhles Junior et al. (1974). After inoculation, all the dogs in both groups were assessed and clinically examined daily, focusing on the animals' body temperature and palpation of abdominal organs and lymph nodes. Individual food and water intakes were also logged and assessed. The possible presence of morulae in capillary blood taken from the ear tip of each animal, up to the time when parasitemia was confirmed, was investigated for all the five infected dogs.

Thirty days after inoculation, the dogs in the infected group were treated orally with $5 \mathrm{mg} / \mathrm{kg}$ of doxycycline hyclate (Doxifin', Ouro Fino) every 12 hours for 21 days (TROY; FORRESTER, 1990). After the end of the experiment, all the dogs tested negative for Ehrlichia canis by means of PCR, and consequently were donated.

The times at which the experiment was assessed were determined based on the behavior of APPs described in Rikihisa et al. (1994) and Shimada et al. (2002), and on the expected disease process of the experimental infection by the $E$. canis Jaboticabal strain (CASTRO et al., 2004), as shown in Table 1.

Immunofluorescent Antibody Test (IFAT) for Ehrlichia canis and Babesia canis - IFAT was performed as described by Camargo (1974) and standardized by Nakaghi et al. (2008) for the $E$. canis system, and as described by Furuta et al. (2009), for the $B$. canis system

DNA extraction and nested PCR (nPCR) analysis - Using the commercially available QIAamp DNA Blood Mini Kit (cat. No. 51104, Qiagen'), DNA was extracted from the blood samples in accordance with the manufacturer's recommendations. For every ten samples, a blank tube containing ultra-pure water (Promega) was included in the DNA extraction, to check the possibility of contamination in this process. A two-step amplification reaction was performed using a thermal cycler (MJ Research; PTC 200), as described by Murphy et al. (1998) and Nakaghi et al. (2008). DNA extracted from the blood of a dog infected with E. canis (Jaboticabal strain) was used as a positive control. In each 
Table 1. Experimental protocol for controls and dogs experimentally infected with the E. canis Jaboticabal strain.

\begin{tabular}{llllcccc}
\hline & \multicolumn{7}{c}{ Days after inoculation } \\
\hline Assessment & 0 & 3 & 6 & 12 & 18 & 30 & 76 \\
Inoculation of E. canis & $\mathrm{X}$ & & & & & & \\
Complete blood count & $\mathrm{X}$ & $\mathrm{X}$ & $\mathrm{X}$ & $\mathrm{X}$ & $\mathrm{X}$ & $\mathrm{X}$ & $\mathrm{X}$ \\
E. canis serology & $\mathrm{X}$ & & & & $\mathrm{X}$ & & $\mathrm{X}$ \\
B. canis serology & $\mathrm{X}$ & & & & $\mathrm{X}$ & & $\mathrm{X}$ \\
nPCR for E. canis & $\mathrm{X}$ & & & & $\mathrm{X}$ & $\mathrm{X}$ \\
APP electrophoretogram & $\mathrm{X}$ & $\mathrm{X}$ & $\mathrm{X}$ & $\mathrm{X}$ & $\mathrm{X}$ & $\mathrm{X}$ & $\mathrm{X}$ \\
Doxycycline treatment & & & & & $\mathrm{X}$ & \\
\hline
\end{tabular}

set of reactions, five tubes containing ultra-pure water (Promega) were used as a template control and they were all cleaned after the amplification procedure. In order to prevent PCR contamination, the DNA extraction, reaction setup, PCR amplification and electrophoresis were performed in separated rooms.

Serum protein electrophoretogram - Protein content was assessed by means of electrophoretic fractioning in a vertical system using the SDS-PAGE method, with the gel prepared as described by Laemmli (1970). Molecular weight and protein fraction levels were determined using readings from a computerized densitometer (Shimatzu CS-9301, Tokyo, Japan) and manual calculation (NAOUM, 1999; THOMAS, 2000; FAGLIARI; SILVA, 2002). To identify the protein content, 10 different markers of molecular weights ranging from 20 to $200 \mathrm{kDa}$, and the purified proteins ceruloplasmin, transferrin, $\alpha_{1}$-antitrypsin, $\mathrm{IgG}$ and haptoglobin were used. The data collection times are described in Table 1.

Statistics - The results obtained in the study were analyzed using analysis of variance for repeated measurements, in which one parameter was the experimental unit (time) and the other parameter was the different groups (control/infected). The group means were compared using Tukey's range test. Values of $\mathrm{p}<0.25$ for the interaction time in each group and of $p<0.05$ between the groups were considered significant. The SAS software (Statistical Analysis System, 2006) was used for the analysis.

\section{Results and Discussion}

The electrophoretograms on the samples collected during the experimental period revealed that 25 protein fractions were present in the densitometric analysis on the serum samples from the animals used in the present study. Of these, five proteins were considered important for the study: ceruloplasmin $(125 \mathrm{kDa})$, transferrin $(79 \mathrm{kDa})$, albumin $(69 \mathrm{kDa})$, haptoglobin $(45 \mathrm{kDa})$ and acid glycoprotein $(40 \mathrm{kDa})$. All the five tagged proteins showed significant $(p<0.25)$ interaction times in each group, thus indicating that, during the study period, the curves followed different trends for the different groups.

The acute phase of canine ehrlichiosis usually manifests eight to 20 days after the host has been infected by the bacteria (TROY; FORRESTER, 1990). All the infected dogs developed inappetence around the $17^{\text {th }}$ day post-inoculation $(\mathrm{PI})$ and presented hyperthermia that peaked between days 12 and $20 \mathrm{PI}$ (39.0 \pm 1.0 and $39.8 \pm 0.4^{\circ} \mathrm{C}$, respectively). In addition to high body temperatures, the infected dogs also presented slight lymphadenomegaly, particularly at the submandibular, prescapular and popliteal lymph nodes. Following the period of hyperthermia, body temperature varied individually in the infected dogs, and high body temperatures were detected until the $28^{\text {th }}$ day PI in one animal (A5). If body temperature reached more than $39.5^{\circ} \mathrm{C}$, the dogs received dipyrone, $28 \mathrm{mg} / \mathrm{kg}$ subcutaneously (SC). Two dogs (A1 and A4) presented splenomegaly after day $14 \mathrm{PI}$, which persisted in both of them until treatment was instituted. Subsequently, the spleen size reduced gradually to normal levels over the course of the treatment. As described by other authors (TROY; FORRESTER, 1990; CASTRO et al., 2004), no clinical or hematological abnormalities were detected in the present study, in any of the animals of the control group during the evaluation period.

Thrombocytopenia (mean platelet count 181,000 \pm 30879 platelets $/ \mu \mathrm{L}$ ) was observed starting on the third day PI (D3) and became statistically significant $(\mathrm{p}<0.01)$ by D6 in the dogs of group A. This persisted until the end of the experimental observation period, even after treatment had been instituted $(181,400 \pm 24,048$ platelets $/ \mu \mathrm{L}))$. Leukopenia was observed as early as D6 (mean leukocyte count of 5,180 \pm 1361 leukocytes/ $\mu \mathrm{L}, \mathrm{p}=0.03$ ), and persisted until the end of the assessment period (mean leukocyte count 5,180 \pm 746 leukocytes $/ \mu \mathrm{L}$ ). The dogs presented persistent anemia throughout the study, mainly at low levels, detected on D12 (mean erythrocyte count $5,980,000 \pm 266,000$ erythrocytes $/ \mu \mathrm{L}$ ). Higher anemia rates were detected on day D18 $(4,516,000 \pm 198,000, \mathrm{p}<0.01)$ and on D30, when the lowest erythrocyte counts were measured (mean erythrocyte count 4,220,000 $\pm 903,000$ erythrocytes $/ \mu \mathrm{L}, \mathrm{p}<0.01$ ).

Castro et al. (2004) reported that transitory leukopenia appeared in the second week after inoculation of their dogs, and that the leukocyte levels returned to normal during the following week. The onset of thrombocytopenia was found to coincide with that of leukopenia, while the onset of anemia was detected in the first week PI and attained its highest rate in the third week PI (2.900.000 erythrocytes/ $\mu \mathrm{L})$. The assessment of blood cell levels in the present study showed abnormalities similar to those described by Castro et al. (2004), although they occurred much earlier in the development of the infection. This discrepancy was not expected, since both studies used the Jaboticabal strain of E. canis for experimental infection of the dogs. One possible explanation for this difference could be the strain used. While Castro et al. (2004) used the original strain, with a sample which had been 
cryopreserved, the strain in the present study had previously been passed through a line of cultivated canine monocytes (DH82-ATCC, USA). This procedure could have increased the strain's virulence, an occurrence that has already been reported in relation to other infective agents (WELLMAN et al., 1988).

Another possible explanation for the discrepancy could relate to the animals that received the inoculum. Castro et al. (2004) inoculated the E. canis Jaboticabal strain into four-month old German shepherd pups, a breed that is known to develop clinically severe cases of the disease (TROY; FORRESTER, 1990; SHIMADA et al., 2002). Since the animals used in the present study were two-year-old dogs of undefined breed, it would be expected that these would present much milder development of clinical signs. This, however, was not the case. These variations indicate the need for better understanding of the physiopathology of experimental canine ehrlichiosis, since it would seem that factors other than breed and age could be involved in the development of the infection, as well as indicating that different levels of virulence may occur in different samples.

Morulae were found in the cytoplasm of cells from blood taken from the ear tips of three of the five animals in group A (A2, A4 and A5) after D15, which confirmed the presence of bacteremia (or rickettsemia) and E. canis infection. The experimental infection of dogs using the $E$. canis Jaboticabal strain showed minimal variation regarding the time at which the bacteremia (or rickettsemia) is initially detected and also in relation to manifestation of clinical signs, and this is confirmed by the studies of Castro et al. (2004). These authors detected intracytoplasmic morulae from day 12 PI onwards, a time that coincided with occurrence of hyperthermia in the animals, similar to the results found in the present study.

On day 0 all dogs were serologically negative for $E$. canis and $B$. canis by IFAT, confirming that none of the animals had been previously exposed to these organisms. In the subsequent assessments (D18 and D76), the dogs in group B continued to be negative for anti-E. canis antibodies, while the opposite situation was seen among the dogs in group $A$, at both assessment times. The antibody titers ranged from $1: 2,560$ to $1: 5,120$ on D18 and from $1: 320$ to $1: 2,560$ on D76. Reports on experimental infection in German shepherd dogs using the E. canis Oklahoma strain described detection of anti-E. canis antibodies already on the second day PI. These titers were found to increase until the $10^{\text {th }}$ day PI and maintained high levels thereafter, with titers ranging from 1:160 to $1: 10240$ (RIKIHISA et al., 1994). Other authors observed seroconversion in Beagles infected with the same Oklahoma strain, occurring between days 5 and 15 PI with increasing levels, and reaching 1:40,960 on day 65 PI (SHIMADA et al., 2002). E. canis DNA was detected in the dogs of group A only on D18 (Figure 1), and all the dogs became PCR negative after treatment (D76).

The ceruloplasmin levels in group A increased gradually starting on D3, and attained the highest levels on D6 and D12. The same dynamic was observed for acid glycoprotein, and after D12 these levels decreased greatly until D30, when the process reverted. A significant difference $(\mathrm{p}<0.01)$ was found between the groups on days 6 and 12 PI (Figure 2). It seems that an increase in ceruloplasmin levels would be an early indicator of the onset of inflammatory processes in dogs with hemorrhagic gastroenteritis (KOGIKA et al., 2003); in other diseases such as pyometra in bitches (FARIA JUNIOR, 2004), and in canine babesiosis (ULUTAS et al., 2005). This information agrees with our findings, in which the levels of ceruloplasmin peaked shortly after the experimental infection (D6), even before the onset of clinical signs. Nevertheless, no other reports regarding the serum levels of ceruloplasmin in dogs with ehrlichiosis were found, and thus further comparisons with the results found in this study were not possible.

Transferrin, a negative acute-phase protein, behaved as a positive APP and thus differently from what was expected. The levels of this protein in group A increased up until D18, when they reached their highest levels, and then decreased to levels close to those presented basally, before infection. In group B, the levels of transferrin remained almost unaltered throughout the study, except on D30, when a slight decrease in these levels was detected. Significant differences $(p<0.01)$ between the groups were seen on D18 and on D30 (Figure 3). Transferrin levels are found to become elevated in inflammatory processes triggered by some diseases, in the same way as seen with ceruloplasmin. This occurrence was verified in the present study. Rodrigues (2006) also observed more elevated levels of transferrin in bitches subjected to cesarean section surgery, in compared with those that delivered their litters naturally, without surgical intervention. In the same way, dogs that presented positive IFAT reactions to visceral canine

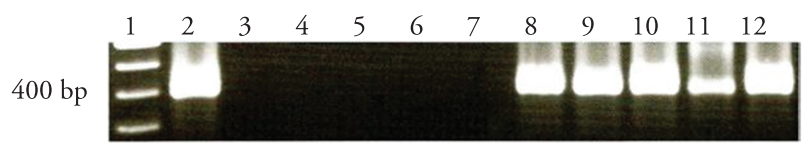

Figure 1. Amplified products from nPCR for detection of E. canis DNA in whole blood samples from the dogs in groups A and B on the $18^{\text {th }}$ day after experimental infection. Column 1: marker of 100 base pairs (bp) for molecular weight. Column 2: positive control. Columns 3 to 7 : animals in group B. Columns 8 to 12 : animals in group A.

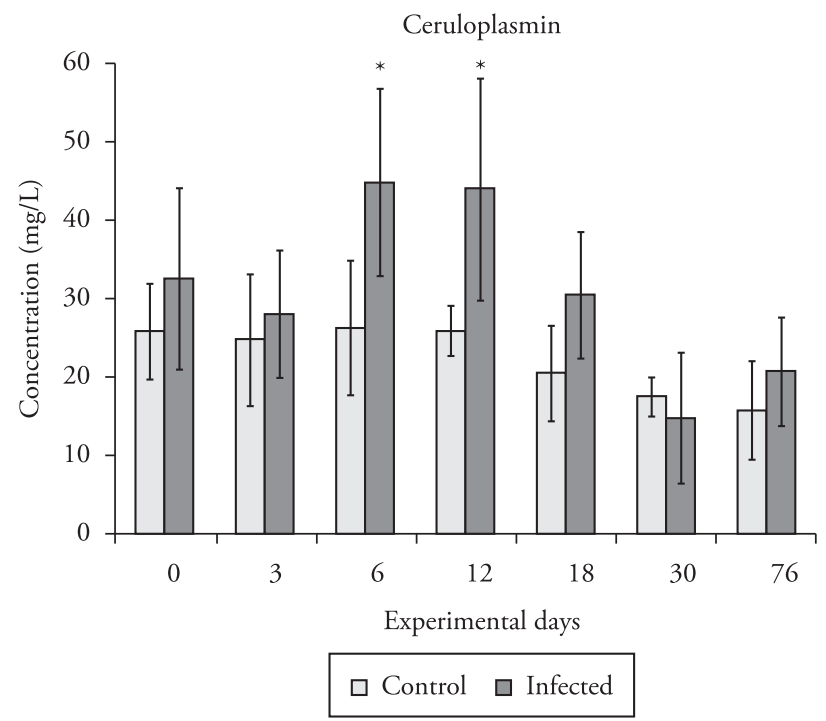

Figure 2. Graphical representation of the averages (vertical bars) and standard deviations (vertical lines) of concentrations of ceruloplasmin in infected and control dogs over the course of the experimental period. *Statistical difference between the groups at the level of $<0.01$. 
leishmaniasis were found to have higher serum levels of this APP than shown by non-infected dogs (RIBEIRO, 2007).

The albumin levels were similar in the two groups up until D12. In the subsequent assessments, on D18 and D30, these levels decreased dramatically in group $\mathrm{A}$, and were found to have become significantly different from group $B(p<0.01$ on $\mathrm{D} 18$ and $\mathrm{p}=0.01$ on D30) (Figure 4). The reduction in serum albumin levels was expected, since it is a negative APP, and this was in accordance with the hypoalbuminemia described in natural canine ehrlichiosis infection (TROY; FORRESTER, 1990; HARRUS et al., 1996; NELSON; COUTO, 1998). Occurrences

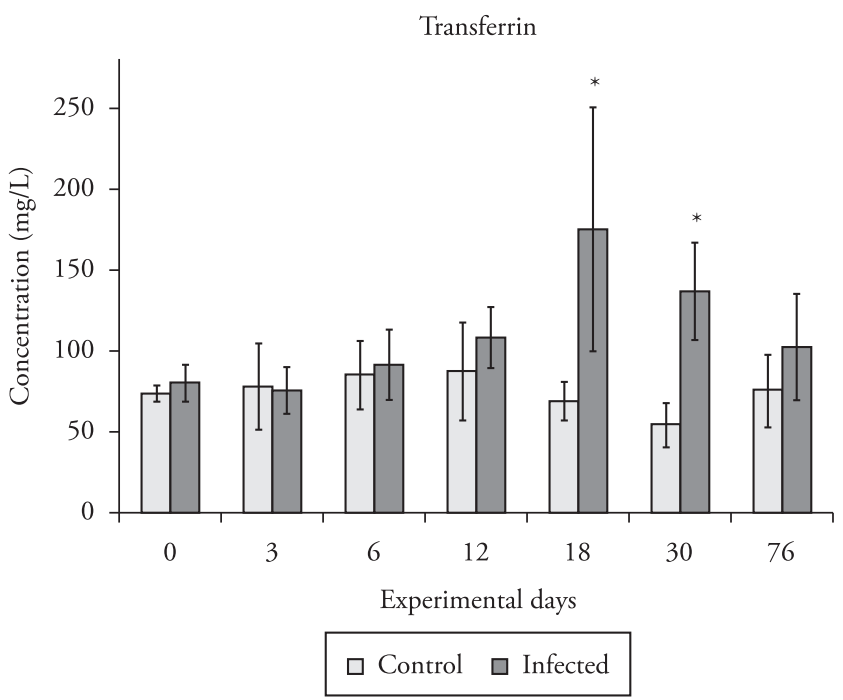

Figure 3. Graphical representation of the averages (vertical bars) and standard deviations (vertical lines) of concentrations of transferrin in infected and control dogs over the course of the experimental period. * Statistical difference between the groups at the level of $<0.01$.

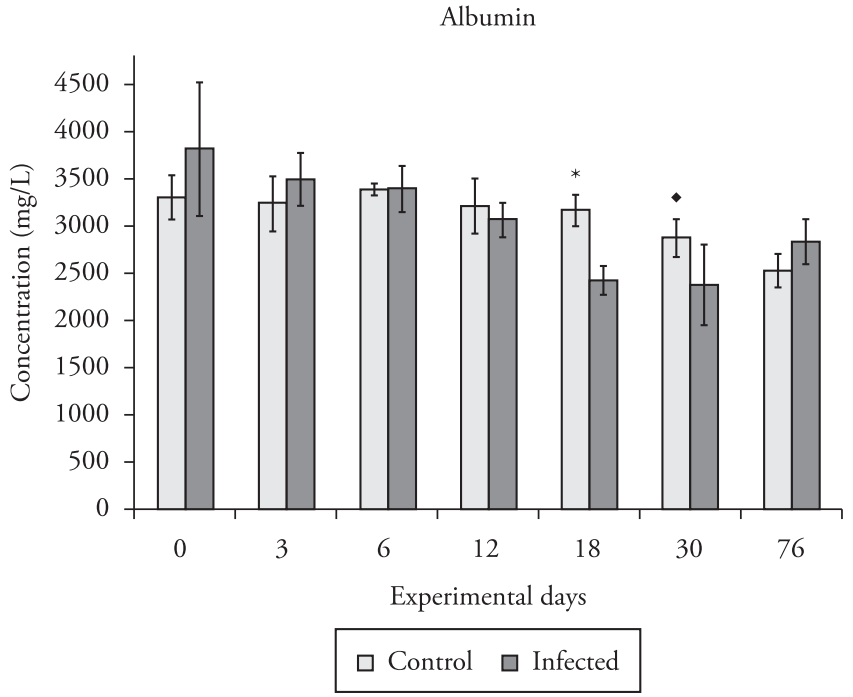

Figure 4. Graphical representation of the averages (vertical bars) and standard deviations (vertical lines) of concentrations of albumin in infected and control dogs over the course of the experimental period. * Statistical difference between the groups at the level of $<0.01$.

- Statistical difference between the groups at the level of 0.01 . of hypoalbuminemia have been attributed to anorexia, peripheral loss of albumin in edema fluid occurring in tissue due to increased vascular permeability, blood loss, nephropathy and decreased protein synthesis due to concomitant liver disease presented by infected dogs (HARRUS et al., 1996).

In group $A$, the haptoglobin levels were highest on D6 and D18. After D18, they gradually decreased until, at the end of the experimental assessment period, they attained levels lower than those presented initially. Group B presented its highest haptoglobin levels on D6 and afterwards on D30, although these were found to be well below those of the infected group. The levels in the infected group declined towards the end of the experimental period, to levels similar to those of Group B. The groups presented a significant difference $(p<0.01)$ in the results only on D18 (Figure 5). Although not in relation to canine ehrlichiosis, haptoglobin levels had already been assessed in many studies in relation to infectious diseases (KOGIKA et al., 2003; DABROWSKI et al., 2007; MATIJATKO et al., 2007), inflammatory diseases (BAYRAMLI; ULUTAS, 2008; LOWRIE et al., 2009) and neoplasia (MISCHKE et al., 2007). Under all the conditions described, haptoglobin levels were found to be higher than under normal conditions. Bayramli and Ulutas (2008) considered that this APP was an important marker for inflammation and infection, and that it would be useful for monitoring treatment and evaluating disease prognosis among dogs.

The serum levels of acid glycoprotein in group A started to rise on D3, peaked on D12, and afterwards decreased to levels similar to those presented on D0, with significant differences $(p<0.01)$ between the groups on D6 and D12. The levels in the control group did not differ significantly $(p>0.05)$ throughout the assessment period (Figure 6). According to Rikihisa et al. (1994), acid glycoprotein can be used as a tool for assessing the severity of inflammatory lesions in dogs with ehrlichiosis. These

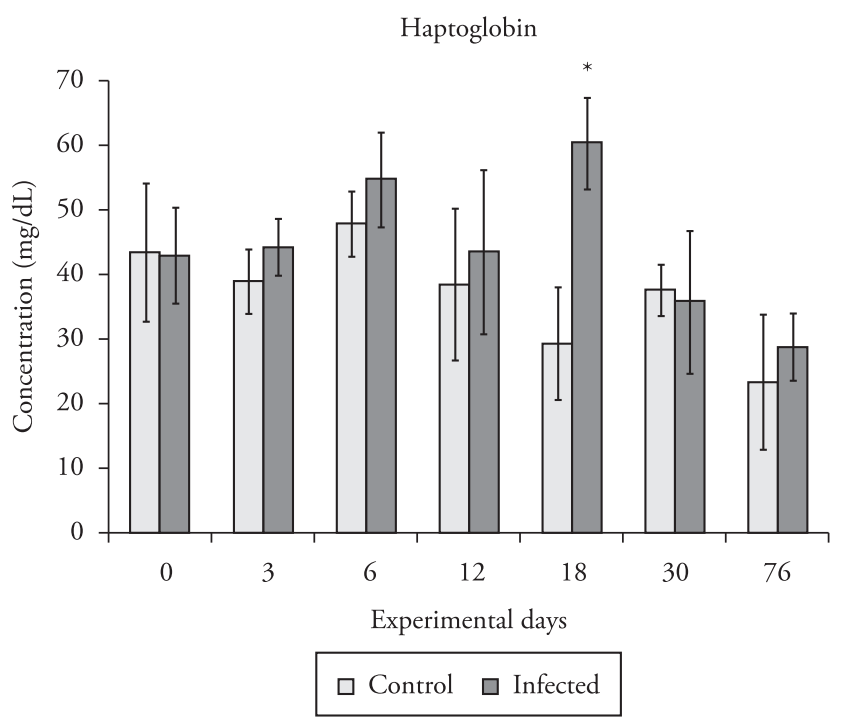

Figure 5. Graphical representation of the averages (vertical bars) and standard deviations (vertical lines) of concentrations of haptoglobin in infected and control dogs over the course of the experimental period. *Statistical difference between the groups at the level of $<0.01$. 
Acid glycoprotein

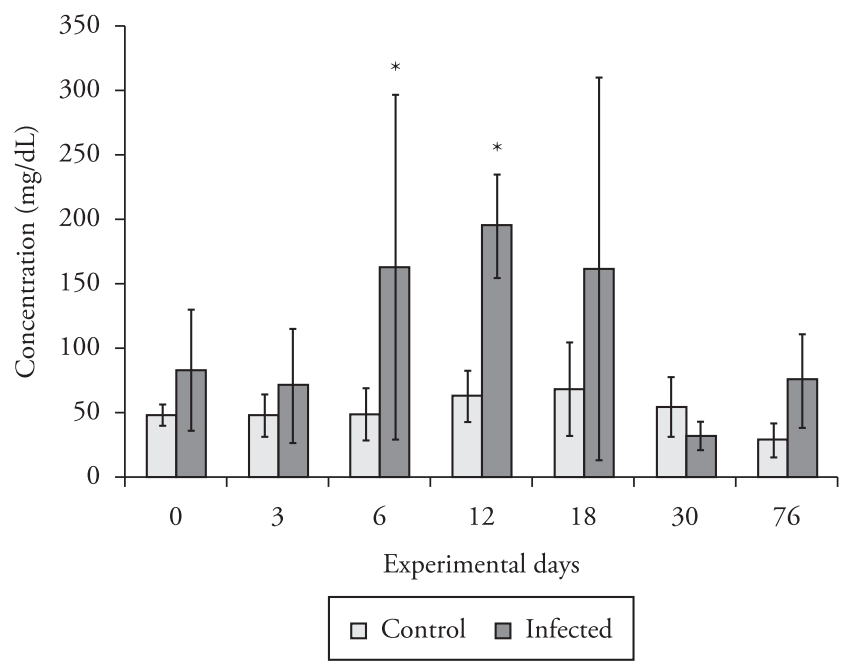

Figure 6. Graphical representation of the averages (vertical bars) and standard deviations (vertical lines) of concentrations of acid glycoprotein in infected and control dogs over the course of the experimental period. ${ }^{*}$ Statistical difference between the groups at the level of $<0.01$.

authors reported an increase in the levels of this protein as early as on the second day PI, in German shepherd dogs infected with the Oklahoma strain. The differences found regarding the peaks of acid glycoprotein levels could be attributed to the strain of E. canis used in the infections, which, as already discussed earlier, could present different levels of pathogenicity. Furthermore, the concentration of the inoculum and the breed of the dogs used in the experimental infection could exert influences on these results, as could the fact that, in the present study, the assessments were not performed daily, as they were in the study by Rikihisa et al. (1994).

In general, starting on $\mathrm{D} 3$, all the APPs presented altered levels in relation to D0. However, the highest APP levels were observed on D18, with the exception of ceruloplasmin and acid glycoprotein, which attained their highest levels earlier, respectively on D6 and D12. Interestingly, on these days, the infected dogs presented the highest detected body temperature. Also, blood smears from samples collected from the dogs' ear tips on these same days showed the presence of morulae, and the onset of clinical signs and all the significant alterations in blood cell levels (pancytopenia) occurred on these dates. At this stage of the disease, increased APP levels, which are considered to be part of an unspecific response of the immune system, could be triggered in an attempt to stimulate the adaptive immune system. This could be an attempt to resolve the infection, thereby avoiding the escape mechanisms developed by the parasite. It is worth reiterating that these results were obtained under conditions of experimental infection, and that different results might be achieved under conditions of natural disease.

\section{Conclusions}

Even though APPs are considered to be part of the unspecific response of the immune system, the present study was able to infer that they are also directly involved in the inflammatory process generated by experimental infection by E. canis, and that the levels of these proteins change very early in the development of the infection. For this reason, these specific proteins could contribute towards early diagnosis of canine ehrlichiosis. Among the different APPs, acid glycoprotein and ceruloplasmin, in particular, would be the most useful for this purpose, since their levels were found to be higher even before the onset of clinical signs and before detection of laboratory alterations that signal the occurrence of infection.

\section{Acknowledgements}

The authors would like to thank the Immunoparasitology Laboratory of FCAV/UNESP Jaboticabal, for its help in carrying out serological and nPCR assays, and the Research Support Foundation of the State of São Paulo (Fundação de Amparo à Pesquisa do Estado de São Paulo) for providing funding through a Masters degree scholarship (2007/53552-0) and a research grant (2007/55577-0)

\section{References}

Bayramli G, Ulutas B. Acutephase protein responsein dogswith experimentally induced gastric mucosal injury. Vet Clin Pathol 2008; 37(3): 312-316. PMid:18761525.

Buhles Junior WC, Huxsoll DL, Ristic M. Tropical canine Pancytopenia: clinical, hematologic, and serologic response of dogs to Ehrlichia canis infection, tetracycline therapy, and challenge inoculation. J Infect Dis 1974; 130(4): 357-367. PMid:4140878.

Camargo ME. Introdução às técnicas de imunofluorescência. Rev Bras Patol Clin 1974; 10(3): 87-107.

Castro MB, Machado RZ, Aquino LPCT, Alessi AC, Tinucci-Costa M. Experimental acute canine monocytic erhlichiosis: clinicopathological and immunopathological findings. Vet Parasitol 2004; 119(1): 73-86. http://dx.doi.org/10.1016/j.vetpar.2003.10.012

Cerón LL, Eckersall PD, Martinez-Subiela S. Acute phase proteins in dogs and cats: current knowledge and future perspectives. Vet Clin Pathol 2005; 34(2): 85-99. PMid:15902658.

Cray C, Zaias J, Altman NH. Acute phase response in animals: a review. Comp Med 2009; 59(6): 517-526. PMid:2798837.

Dabrowski R, Wawron W, Kostro K. Changes in CRP, SAA and haptoglobin produced in response to ovariohysterectomy in healthy bitches and those with pyometra. Theriogenology 2007; 67(2): 321-327. http://dx.doi.org/10.1016/j.theriogenology.2006.07.019

Dagnone AS, Morais HAS, Vidotto MC, Jojima FS, Vidotto O. Ehrlichiosis in anemic, thrombocytopenic, or tick-infested dogs from a hospital population in South Brazil. Vet Parasitol 2003; 117(4): 285-290. http://dx.doi.org/10.1016/j.vetpar.2003.10.001

Fagliari JJ, Silva SL. Hemograma e proteinograma plasmático de eqüinos hígidos e de eqüinos acometidos por abdômen agudo, antes e após laparotomia. Arq Bras Med Vet Zoo 2002; 54(6): 559-67. http://dx.doi. org/10.1590/S0102-09352002000600001

Faria Junior D. Caracterização citológica e bioquímica do sangue e do lavado peritoneal em cadelas com piometra [Tese]. Jaboticabal: Faculdade de Ciências Agrárias e Veterinárias; 2004. 
Faria JLM, Dagnone AS, Munhoz TD, João CF, Pereira WAB, Machado RZ, et al. Ehrlichia canis morulae and DNA detection in whole blood and spleen aspiration samples. Rev Bras Parasitol Vet 2010; 19(2): 98-102. http://dx.doi.org/10.4322/rbpv.01902006

Furuta PI, Oliveira TMFS, Teixeira MCA, Rocha AG, Machado RZ, Tinucci-Costa M. Comparison between a soluble antigen-based ELISA and IFAT in detecting antibodies against Babesia canis in dogs. Rev Bras Parasitol Vet 2009; 18(3): 41-45. http://dx.doi.org/10.4322/ rbpv.01803007

Gabay C, Kushner I. Acute-phase proteins and other systemic responses to inflammation. NEnglJ Med 1999; 340(6): 448-454. PMid:9971870.

Gordon AH. Electrophoresis of proteins in polyacrylamide and starch gels. New York: Elsever Science Publishers; 1975.

Harrus S, Waner T, Avidar Y, Bogin E, Peh H, Bark H. Serum protein alterations in canine ehrlichiosis. Vet Parasitol 1996; 66(3-4): 241-249. http://dx.doi.org/10.1016/S0304-4017(96)01013-8

Kaneko JJ, Harvey JW, Bruss ML. Clinical biochemistry of domestic animals. San Diego: Academic Press; 1997.

Kogika MM, Pereira DA, Elias F, Notomi MK, Delayte EH, Kawahara $\mathrm{R}$ et al. Determinação sérica de haptoglobina, ceruloplasmina e $\alpha$-glicoproteína ácida em cães com gastrenterite hemorrágica. Cienc Rural 2003; 33(3): 513-517. http://dx.doi.org/10.1590/S010384782003000300019

Laemmli UK. Cleavage of structural proteins during the assembly of the head of bacteriophage $\mathrm{T}_{4}$. Nature 1970; 227(5259): 680-685. http:// dx.doi.org/10.1038/227680a0

Lewis GE, Ristic M, Smith RD, Lincoln T, Stephenson EH. The brown dog tick Rhipicephalus sanguineus and the dog as experimental hosts of Ehrlichia canis. Am J Vet Res 1977; 32(12): 1953-1955. PMid:596693.

Lowrie M, Penderis J, Eckersall PD, McLaughlin M, Mellor D, Anderson TJ. The role of acute phase proteins in diagnosis and management of steroid-responsive meningitis arteritis in dogs. Vet J2009; 182(1): 125-130. http://dx.doi.org/10.1016/j.tvjl.2008.05.001

Matijatko V, Mrljak V, Kis I, Kucer N, Forsek J, Zivicnjak T, et al. Evidence of an acute phase response in dogs naturally infected with Babesia canis. Vet Parasitol 2007; 144(3-4): 242-250. http://dx.doi. org/10.1016/j.vetpar.2006.10.004

Mischke R, Waterston M, Eckersall PD. Changes in C-reactive protein and haptoglobin in dogs with lymphatic neoplasia. Vet J2007; 174(1): 188-192. http://dx.doi.org/10.1016/j.tvjl.2006.05.018

Murphy GL, Ewing SA, Whitworth LC, Fox JC, Kocan AA. A molecular and serologic survey of Ehrlichia canis, E. chaffeensis and E. ewingii in dogs and ticks from Oklahoma. Vet Parasitol 1998; 79(4): 325-339. http:// dx.doi.org/10.1016/S0304-4017(98)00179-4

Nakaghi ACH, Machado RZ, Tinucci-Costa M, André MR, Baldani CD. Canine ehrlichiosis: clinical, hematological, serological and molecular aspects. Cienc Rural 2008; 38(3): 766-770. http://dx.doi.org/10.1590/ S0103-84782008000300027

Naoum PC. Eletroforese - técnicas e diagnósticos. Rio de Janeiro: Livraria Santos; 1999.

Nelson RW, Couto CG. Medicina interna de pequenos animais. Rio de Janeiro: Guanabara-Koogan; 1998.

Ribeiro CR. Aspectos clínicos, epidemiológicos e laboratoriais de cães sororreagentes para leishmaniose visceral, em foco de transmissão no Distrito Federal-DF-Brasil [Tese]. Jaboticabal: Faculdade de Ciências Agrárias e Veterinárias; 2007.

Rikihisa Y, Yamamoto S, Kwak I, Iqbal Z, Kociba G, Mott J, et al. C-reactive protein and $\alpha 1$-acid glycoprotein levels in dogs infected with Ehrlichia canis. J Clin Microbiol 1994; 32(4): 912-917. PMid:263162.

Rodrigues V. Hemograma, teores séricos de proteinas e de cortisol de fêmeas caninas (Canis familiaris - LINNAEUS, 1758) submetidas à operaçāo cesariana [Dissertaçáo]. Jaboticabal: Faculdade de Ciências Agrárias e Veterinárias; 2006.

Shimada T, Ishida Y, Shimizu M, Nomura M, Kawato K, Iguchi K, et al. Monitoring C-reative protein in beagle dogs experimentally inoculated with Ehrlichia canis. Vet Res Commun 2002; 26(3): 171-177. http:// dx.doi.org/10.1023/A:1015290903332

Thomas JS. Protein electrophoresis. In: Feldman BV, Zinkl JG, Jain NC. Schalm's Veterinary Hematology. Philadelphia: Lippincott Williams \& Wilkins; 2000. p. 899-903.

Trautwein C, Böker K, Manns MP. Hepatocyte and immune system: acute phase reaction as a contribution to early defence mechanisms. Gut 1994; 35(9): 1163-1166. PMid:7525420.

Troy GC, Forrester SD. Canine ehrlichiosis. In: Greene CE. Infectious diseases of the dog and cat. Philadelphia: Saunders; 1990. p. 404-418.

Ulutas B, Bayramli G, Ulutas PA, Karagenc T. Serum concentration of some acute phase proteins in naturally occurring canine babesiosis: a preliminary study. Vet Clin Pathol 2005; 34(2):144-147. PMid:15902667

Vieira RFC, Biondo AW, Guimarães AMS, Santos AP, Santos, RP, Dutra LH, et al. Ehrlichiosis in Brazil. Rev Bras Parasitol Vet 2011; 20(1): 1-12. http://dx.doi.org/10.1590/S1984-29612011000100002

Wellman ML, Krakowka S, Jacobs RM, Kociba GJ. A macrophagemonocyte cell line from a dog with malignant histiocytosis. In Vitro Cell Dev Biol 1988; 24(3): 223-229. http://dx.doi.org/10.1007/BF02623551 